\title{
The EU Expansion and the Draft Constitution: A Redesigned Europe for the 21st Century?
}

\author{
Giuseppe Schiavone
}

\section{Introduction}

The endeavour to produce a constitutional text replacing the existing treaties and streamlining and improving the institutional framework and decision-making machinery of European integration is closely linked to the approaching expansion of the European Union (EU). Previous enlargements had required adjustments on several planes without changing, however, the basic criteria concerning members' representation in the EU institutions and their corresponding "weight" in the decision-making process. The "big bang" enlargement scheduled to take place on 1 May 2004 represents a turning point in the EU's half-century-old history that is not only swelling the membership but also calling into question longestablished procedures and practices. As a consequence, the cosy old western European home must be abandoned and residents, old-timers as well as newcomers, have to move to a more spacious and hopefully better equipped pan-European building, with a new formal set of rules for its governance.

Between 1973 and 1995 the original structures, as conceived in the 1950s, had been progressively adapted and stretched to make room for the new entrants but the time has now come to devise new formulas in a truly continental perspective. Throughout four long decades since the conclusion of World War II the objective of bringing together the countries of Europe was considered to all intents and purposes in a purely western European context. Because of cold-war divisions, until the very end of the 
The EU Expansion and the Draft Constitution : A Redesigned Europe for the 21st Century? (Schiavone)

1980s, the area known as "eastern Europe", approximately located between the Baltic and Adriatic seas, was routinely regarded as part of a "bloc" dominated by the then USSR and on many accounts all but unrelated to the non-communist part of the continent.

Although several international organizations labeled themselves European such as the Council of Europe, the then Organization for European Economic Cooperation (OEEC), the European Free Trade Association (EFTA) or the European Communities their membership was in actual fact restricted, and rightly so, to countries situated in the western half of the continent.

The collapse of the Soviet external and internal empire brought about a dramatic wave of changes on the European continent with the emergence, in its eastern part, of countries gradually moving towards the same fundamental goals, values and objectives of western European nations on the political as well as on the economic plane. It is not by chance that, in the 1990s, the countries of central and eastern Europe were classified by major international institutions as "countries in transition".

Despite the ongoing unification process, the European institutional landscape remains characterized by a variety of trans-regional, regional and subregional groupings that in a number of cases comprise as full members countries belonging to other continents, in particular North America and Central Asia. In this connection, mention may be made of the "transregional" Europe of the Organization for Security and Cooperation in Europe (OSCE) and of the United Nations Economic Commission for Europe (UN/ECE) with 55 members each; the "European" Europe of the Council of Europe with 45 members; the "North Atlantic" Europe of NATO with 19 members and the 15-member EU. Both NATO and the EU will considerably increase their membership by mid -2004 thanks to a substantial intake of central and eastern European countries.

Ever since the beginning of the end for socialist regimes in Europe, western European institutions and above all the European Communities 


\section{『日本 $\mathrm{EU}$ 学会年報』第 24 号, 平成16年 9 月}

have effectively supported central and eastern European countries eager to "return" to the European fold after decades of artificial separation. The Phare programme for financial assistance to the economic restructuring of Poland and Hungary was launched by the Group of Seven (G-7) in 1989 and came into operation the following year, under the administration of the European Commission. It was gradually extended to other "transition" economies and played a key role in the EU's pre-accession strategy.

In the 1990s, bilateral association agreements, the so-called Europe Agreements, were negotiated by the EU with central and eastern European countries. The first Europe Agreements were concluded in 1991 with then united Czechoslovakia, Hungary and Poland and were followed by those with Bulgaria in 1995, the Baltic countries and Slovenia in 1996, and Romania in 1997. Europe Agreements were essentially meant to provide a basis for the gradual integration into the $\mathrm{EU}$ of the associated countries. On the other hand, no Europe Agreements were signed with the republics belonging to the former USSR (with the exception of the three Baltic countries) but only Partnership and Co-operation Agreements providing for looser ties.

The European Council meeting in Copenhagen on 21-22 June 1993 decided that "the associated countries in central and eastern Europe that so desire shall become members" of the EU $\stackrel{2}{\text { ) }}$ Full membership was therefore to be granted to any applicant from central and eastern Europe prepared to meet the "Copenhagen criteria" : to be a functioning and stable democracy, with an economic system, based on free market principles, that can cope with competitive pressures, and be able to assume all the obligations of membership.

Membership applications were presented by Hungary and Poland in 1994, Romania, Slovakia, Latvia, Estonia, Lithuania and Bulgaria in 1995, and the Czech Republic and Slovenia in 1996, thus paving the way for the eastward expansion of the EU. The break-up of cold-war blocs in Europe also had an impact on the EU's westward enlargement that was all but 
The EU Expansion and the Draft Constitution: A Redesigned Europe for the 21st Century? (Schiavone)

completed on 1 January 1995 with the accession of Austria, Finland and Sweden.

At the Copenhagen European Council of December 2002, an enlargement on an unprecedented scale was decided following the conclusion of accession negotiations with ten countries:the Baltic nations (Estonia, Latvia, Lithuania), the Czech Republic, Hungary, Poland, Slovakia, Slovenia and the two Mediterranean island states of Cyprus and Malta. These countries will officially join the EU on 1 May 2004 and their citizens will take part in the elections of the European Parliament scheduled to take place by mid-June 2004. At Copenhagen, "road maps" were approved for Bulgaria and Romania while a decision on the opening of accession negotiations with Turkey was postponed.

Besides Croatia that formally applied for membership in February 2003 and could join in 2007, together with Bulgaria and Romania, and Macedonia that is expected to introduce its application soon, other prospective candidates in southeastern Europe include Albania, Bosnia and Herzegovina, and Serbia and Montenegro.

The 1986 Single European Act, the 1992 Maastricht Treaty, the 1997 Amsterdam Treaty and the 2001 Nice Treaty marked crucial, if only partly successful, attempts at upgrading and speeding up the integration process, contributing to the development of the EU experience. It need not be emphasized that the driving force behind European integration has been political and that the "founding fathers" of Europe started a process that made use of economic tools to attain essentially political ends.

Over the past decade, fundamental principles have been elaborated to incorporate liberty, democracy, the rule of law and respect for human rights (including basic social rights of workers), considered not only prerequisites for countries aspiring to join the EU but also conditions for outsiders in order to obtain development aid. As for the objectives, these were expanded to embrace, inter alia, the achievement of "balanced and sustainable development", a common foreign and security policy, including 
the progressive framing of a common defence policy, and the establishment of an area of freedom, security and justice.

The willingness and ability to forge a strong regional or subregional identity is a characteristic aspect of the most developed integration groupings and of the EU in particular. It is worth stressing the importance of the creation, in the 1990s, of a "citizenship of the Union" complementing national citizenship. The physical introduction of euro notes and coins for all member countries but three in January 2002 is another powerful symbol of European identity.

\section{The Convention on the future of Europe}

Following the agreement reached in December 2000 in Nice, the heads of state or government meeting at Laeken, on the outskirts of Brussels, on 14 and 15 December 2001, adopted the "Declaration on the Future of the European Union" and decided to set up a Convention composed of the main parties involved in the debate about the prospects of European integration. Although the ultimate decisions on the reform of the European treaties continue to fall within the responsibility of specially convened gatherings of the representatives of the governments of member countries meeting as an Intergovernmental Conference (IGC), it was felt necessary at Laeken to dispel the aura of secrecy that often characterizes multilateral negotiations. The Convention would thus pave the way for the next IGC through a broad and open discussion of the key issues at stake and of the various possible responses.

This new course of action would contribute to making the EU more democratic, transparent and efficient, meeting three basic challenges:how to bring citizens, and primarily the young, closer to the European design and the European institutions; how to organise the European political sphere in view of the enlargement; and how to develop the EU into a stabilising factor and a model in the new world order.

The clarification and adjustment of the division of competence between 
The EU Expansion and the Draft Constitution : A Redesigned Europe for the 21st Century? (Schiavone)

the EU and its member countries were among the basic tasks of the Convention. The simplification of the instruments of action and the relevant decision-making process represented another major challenge, along with the improvement of the functioning of the various institutions and the development of the role of national parliaments in the European architecture.

The Convention was officially inaugurated on 28 February 2002 and concluded its work on 10 July 2003; meetings were held in Brussels using the 11 working languages of the EÜ. The European Council appointed former French president Valéry Giscard d'Estaing as chairman of the Convention and Giuliano Amato of Italy and Jean-Luc Dehaene of Belgium as vice-chairmen. In addition to its chairman and vice-chairmen, the Convention was composed of 15 representatives of the heads of state or government of the member countries (one from each country) and 30 members of national parliaments (two from each country). The 13 candidate countries were fully involved in the Convention's proceedings being represented on the same basis as members, amounting to 13 representatives of the governments and 26 delegates from national parliaments. The European Parliament was represented by 16 members and the Commission by two members. It should be stressed that about 70 of the 105 members of the Convention were parliamentarians. Representatives of the Economic and Social Committee, the Committee of the Regions, and the European Ombudsman attended as observers.

The Praesidium of the Convention was composed of the chairman and vice-chairmen and of nine members drawn from the Convention (the representatives of all the governments holding the Council presidency during the Convention, two representatives of national parliaments, two members of the European Parliament and two of the European Commission).

Comparisons have been made between the task of the conventioneers meeting in Brussels and that of the participants in the Federal Constitu- 
tional Convention in Philadelphia. Although it was clear from the beginning that Brussels 2002-2003 was not going to be a kind of Philadelphia 1787, the debate focused on a number of issues not too dissimilar from the ones that the Americans faced. In Brussels as in Philadelphia a mechanism was to be established to implement a grand design for a more perfect union and solve the dispute between large and small states over distribution of power in the union's institutions.

The end product of the Convention is the "Draft Treaty establishing a Constitution for Europe". The document provides a single text that replaces all the existing treaties, that is the Treaty on European Union (TEU), the Treaty establishing the European Community (TEC), and the acts and treaties which have supplemented or amended them. This will involve the abolition of the current distinction between the Community and the Union and of the now-famous "pillar structure" introduced by the Maastricht Treaty. A single legal personality is attributed to the Union while, under the existing treaties, it is the European Community that is endowed with the legal personality.

In its present form, the draft Constitution consists of a Preamble and four main parts containing a total of 465 articles. Part I, concerning the values, objectives, powers, decision-making procedures and acts, institutions, finances and conditions of membership of the Union, comprises 59 articles; Part II , incorporating the Charter of Fundamental Rights, includes 54 articles preceded by the Charter's own Preamble; Part III is devoted to the policies and functioning of the Union dealt with in 342 articles; Part IV contains the general and final clauses, together with the procedures for adopting and revising the Constitution, and consists of 10 articles.

\section{The basic features of the draft Constitution}

According to the Preamble, the Constitution was prepared by members of the Convention "on behalf of the citizens and states of Europe". This is the first instance in the text where citizens are expressly mentioned and 
The EU Expansion and the Draft Constitution : A Redesigned Europe for the 21st Century? (Schiavone)

come, on paper at least, before the states. The content of the Preamble and above all the possible inclusion of an explicit mention of the religious and spiritual values common to the peoples of Europe have triggered a debate on whether the various components of Europe's heritage should be explicitly listed.

The Charter of Fundamental Rights proclaimed in Nice on 7 December 2000, and now contained in Part II of the draft Constitution, bears witness to the importance of shared values. The reference to common European values also appeared in the Laeken Declaration stating that the EU "is open only to countries which uphold basic values such as free elections, respect for minorities and respect for the rule of law".

In its present version, the Preamble refers to the "cultural, religious and humanist inheritance" of Europe, the values of which are "still present in its heritage". No specific mention is made of God and/or Christianity, despite the impassioned pleas of religious leaders, especially Pope John Paul II , to that effect. Some governments, notably those of Italy and Poland, have called for the inclusion of an appropriate reference to the Christian heritage of the peoples of Europe. As a matter of fact, the mere reference to the "religious" inheritance of Europe seems rather vague; the diverse components of Europe's legacy should be either fully described or left out altogether.

Part I can be considered the "core" of the draft prepared by the conventioneers embodying the fundamental principles governing the Union. The Constitution, at Article I-1(1), establishes the EU as the creation of the citizens and states of Europe in order to build a common future. The founding values are the respect for human dignity, liberty, democracy, equality, the rule of law and respect for human rights (Article I-2). The aim of the EU is to promote peace, its values and the well-being of its peoples.

In the international arena, the EU contributes to peace, security, sustainable development, solidarity and mutual respect among peoples, free and 
fair trade, eradication of poverty and protection of human rights, and in particular children's rights, and strict observance and development of international law, including respect for the principles of the Charter of the United Nations.

With regard to international law, concern has been expressed in some quarters over the lack of a provision explicitly rejecting war as a means of settlement of international disputes and affirming the opposition of "old Europe" to the now-popular strategies based on "pre-emptive" armed intervention for the purpose of self-defence. The Italian Constitution, for instance, states in Article 11 that Italy repudiates war as a means to solve international disputes; for its part, Article 26 of the German Constitution explicitly forbids the preparation of an offensive war.

Citizenship of the EU is dealt with in Article I -8 of the draft Constitution stating that "every national of a member state shall be a citizen of the Union". Since EU citizenship is considered as "additional", it is not intended to replace national citizenship but complements it. There seems to be no chance, for the foreseeable future, of an EU citizenship supplanting national citizenship.

The rights stemming from citizenship are:freedom to move and reside freely within the territory of the member countries; to vote and stand as candidates in elections to the European Parliament and municipal elections in the member country of residence; to enjoy the protection of the diplomatic and consular authorities of any member country in the territory of a third country in which their own country is not represented; to petition the European Parliament and to apply to the European Ombudsman "in any of the Constitution's languages".

As regards the relationship between the EU and member states, the "principle of loyal cooperation" is clearly stated in Article I -5(2) with the ensuing obligation to assist each other, in full mutual respect, in carrying out the tasks arising from the Constitution.

The fundamental issue of the categories of competence of the Union is 
The EU Expansion and the Draft Constitution: A Redesigned Europe for the 21st Century? (Schiavone)

dealt with by the draft Constitution that distinguishes between areas of "exclusive competence", areas of "shared competence", and areas of "supporting, coordinating or complementary action". It should be pointed out that the classification is aimed at describing more clearly the existing powers of the Union rather than at extending them.

The principle of conferral implies that the EU can act only to the extent that member countries have given competence to it. On the basis of subsidiarity, the Union is required to act only if the objectives cannot be sufficiently achieved by members, either at the national or the local level, or where, because of scale, the objectives can be better achieved at EU level. However, the action of the Union, according to the principle of proportionality, cannot exceed "what is necessary to achieve the objectives of the Constitution".

Exclusive competence (Article $\mathrm{I}-12$ ) is reserved to the EU for the establishment of the competition rules necessary for the functioning of the internal market and in the following areas:monetary policy (for countries adopting the euro); common commercial policy; customs union; and the conservation of marine biological resources under the common fisheries policy.

Shared competence (Article I-13) applies in the following main areas: internal market; area of freedom, security and justice; agriculture and fisheries (excluding marine biological resources); transport and transEuropean networks; energy; social policy; economic, social and territorial cohesion; environment; consumer protection; common safety concerns with regard to public health. Special provisions apply in the areas of research, technological development and space, and also for development cooperation and humanitarian aid.

Areas for supporting, coordinating or complementary action (Article I 16) relate to industry, human health, education and vocational training, sport, culture, civil protection.

The classification of competences is completed by a "flexibility clause" 


\section{『日本 $\mathrm{EU}$ 学会年報』第 24 号, 平成16年 9 月}

(Article I -17) stating that in case action by the Union proves necessary to attain an objective set by the Constitution but the Constitution does not envisage the necessary powers, the Council of Ministers "shall take the appropriate measures" acting unanimously on a proposal from the Commission and after obtaining the consent of the European Parliament.

The trend is strengthening for the decision-making process to be based more and more on qualified majority but unanimity remains in a number of sensitive areas, from foreign policy and defence to fiscal policy, to asylum, to social policy and immigration.

The issues concerning EU membership are dealt with at the end of Part I stating the conditions of eligibility, the procedure envisaged for accession and the eventuality of suspension of membership rights (Articles I -57 and I -58). The European treaties presently in force do not contemplate the possibility for a member to leave the Union, an event hardly conceivable with a limited number of highly integrated members. The prospect of an expanding membership, however, has induced the conventioneers to formulate an exit procedure, as is generally the case for most international organizations. According to Article I -59(1) of the draft Constitution, "any member state may decide to withdraw $(\cdots)$ in accordance with its own constitutional requirements". The EU shall conclude an agreement with the country that intends to withdraw in order to define the relevant arrangements taking into consideration the framework for the future relationship with that country.

\section{An institutional framework for a wider Europe}

According to Article I-18(1) of the draft Constitution, the EU is endowed with a structure aiming to promote its objectives and values and serve its interests, its citizens and its member countries. The challenge facing the conventioneers was that of ensuring a fair balance between the different institutions, their powers and responsibilities as well as of stressing the central role of the citizens in the process of European integration. 
The EU Expansion and the Draft Constitution : A Redesigned Europe for the 21st Century? (Schiavone)

The principle of the equality of citizens and their right to "receive equal attention from the Union's institutions" is enshrined in Article I -44 entitled to the "principle of democratic equality". Article I-45(1) states that representative democracy will represent the foundation of the working of the EU. The institutions are under the obligation to give citizens and representative associations the possibility of maintaining a regular dialogue; in this connection, broad consultations will be carried out by the Commission with the interested parties. The possibility of the direct initiative of citizens with a view to ensuring the implementation of a provision of the Constitution is envisaged in Article I -46(4). When citizens consider that a legal act of the Union is necessary to that effect, at least one million people from a significant number of member countries "may invite the Commission to submit any appropriate proposal".

Article I-45 (2) of the draft Constitution declares that "citizens are directly represented at Union level in the European Parliament". On the other hand, member countries are represented in the European Council and in the Council of Ministers by their governments that are "accountable to national parliaments, elected by their citizens".

According to Article I-19(1), the European Parliament, jointly with the Council of Ministers, enacts legislation (the so-called co-decision procedure), exercises the budgetary function, as well as functions of political control and consultation, and elects the President of the Commission. The members of the European Parliament shall not exceed the number of 736 . Representation will continue to be linked to the size of the population of each country but it will also be "degressively proportional", with a minimum threshold of four members per country. In other words, large countries will have fewer and small countries more seats at the European Parliament than a strict application of the population rule would imply.

The European Council, consisting of the heads of state or government of member countries together with its president and the president of the Commission, has become part of the single institutional framework of the 


\section{『日本 $\mathrm{EU}$ 学会年報』第24号, 平成16年 9 月}

$\mathrm{EU}$ as an autonomous body (Article I-20). Unlike the present rules, the European Council is expected to meet more frequently, every three months instead of twice a year.

With a view to avoiding the pitfalls associated with the current sixmonth rotating presidency, further complicated by the forthcoming rise in the number of member countries, the conventioneers have introduced in Article I -21 a new figure represented by the full-time chair of the European Council. The President of the European Council, elected by qualified majority for a two-and-a-half year term renewable once, will be in charge of the preparation and continuity of the Council's work and will ensure the external representation of the EU. The post of president has been conceived as a full-time position and, unlike the present formula, the incumbent may not hold a national mandate.

Another major innovation devised by conventioneers regards the appointment of the Union Minister for Foreign Affairs who will responsible for carrying out the common foreign and security policy of the EU (Article I -27). The Minister will be appointed by the European Council, voting by qualified majority. The agreement of the President of the Commission is also required since the Minister will be one of the Vice Presidents of the Commission itself. In fact, the newly-created post merges the functions of both the present High Representative of the Council for the common foreign and security policy and the Commissioner responsible for external relations.

The Council of Ministers, jointly with the European Parliament, enacts legislation through the co-decision procedure and exercises the budgetary function; it carries out policy-making and coordinating functions (Article I 22 (1)). For the sake of clarity, the full (and clearer) denomination of Council of Ministers has been reintroduced instead of the present one, that is Council.

The basic formations of the Council, dealt with by Article I-23, are the Legislative and General Affairs Council, ensuring consistency in the work 
The EU Expansion and the Draft Constitution : A Redesigned Europe for the 21st Century? (Schiavone)

of the Council itself, and the Foreign Affairs Council. Further formations will be decided by the European Council that will also decide on the rotation of the presidency of the Council of Ministers for periods of at least a year.

As regards the thorny issue of qualified majority voting (QMV), a serious attempt has been undertaken by conventioneers to redress a system characterized by significant anomalies and heavily tilted in favour of smaller countries. According to Article I-24 of the draft Constitution that defines the new qualified majority, the traditional formula of "weighted voting" - adjusted for each wave of enlargement, lastly revised by the Nice Treaty and further framed to benefit smaller countries would be abandoned and replaced in 2009 by a more equitable system based on "double majority". In fact, the qualified majority should consist, from 1 November 2009 , of the majority of member countries representing at least three fifths of the population of the EU; a majority of two thirds of member countries and at least three-fifths of the population would be required in a number of circumstances.

The European Commission is called by Article I-25(1) of the draft Constitution to "promote the general European interest and take appropriate initiatives to that end". This confirms the peculiar "supranational" role of the Commission that makes it stand out in the institutional landscape of regional integration arrangements.

When the EU is enlarged to 25 members in May 2004, every country will appoint a commissioner so that the five largest countries that presently have two commissioners each will lose one from 1 November 2004. As from 1 November 2009, Article I -25(3) restricts the size of the Commission by allowing just 15 voting members and 10 non-voting members.

It is worth stressing that members of the first group will bear the name of "European commissioners" while the non-voting members are simply called "commissioners". The President of the Commission, as stated by Article I-26(3), shall lay down guidelines for the work of the Commis- 


\section{『日本 $\mathrm{EU}$ 学会年報』第24号, 平成16年 9 月}

sion, decide its internal organization and appoint Vice Presidents. A European commissioner or a (non-voting) commissioner must resign upon request of the president.

Article I-28 concludes the Chapter of the draft Constitution devoted to the EU's institutional framework. The Court of Justice, according to the said Article, consists of the European Court of Justice, the High Court and specialized courts, ensuring respect for the law in the interpretation and application of the Constitution. The Court of Justice is called to rule on actions brought by a member country, an institution or a natural or legal person and on other cases provided for in the Constitution, and to give preliminary rulings.

\section{The draft Constitution's catalogue of human rights}

The provisions of Part II of the draft Constitution give the EU its own catalogue of rights. It should be emphasized that the insertion of the full text of the Charter of Fundamental Rights, with only minor technical adjustments, has bestowed on the document constitutional status. The institutions, bodies and agencies of the EU, as well as member countries, are under the obligation to respect the rights listed in the Charter whose provisions are binding; this does not mean, however, an extension of the Union's powers. The provisions of Part II are broader than those contained in the European Convention for the protection of human rights and fundamental freedoms, signed in Rome on 4 November 1950, under the auspices of the Council of Europe. While the European Convention deals only with civil and political rights, Part II covers several other areas, including the protection of personal data, the social rights of workers and the right to proper administration. According to the draft Constitution, the EU will endeavour to adhere to the European Convention. The eventual adhesion to the Convention, however, would in no way increase the powers of the EU.

The Charter consists of 54 Articles, headed by a Preamble, distributed in 
seven chapters : Dignity, Freedoms, Equality, Solidarity, Citizens' Rights, Justice, and General Provisions. The Preamble stresses that the Union "places the individual at the heart of its activities, by establishing the citizenship of the Union and by creating an area of freedom, security and justice". The catalogue of fundamental rights provided by the Charter is unquestionably extensive; due account is taken, as declared in the Preamble, of "changes in society, social progress and scientific and technological developments".

The rights listed in the Charter may be divided into three broad categories. First of all there are the basic universal rights related to human dignity such as the right to life and the right to the integrity of the person, extended to the fields of medicine and biology to include also the prohibition of the "reproductive cloning of human beings". Next come the civil and political rights which are associated with citizenship of the Union. A third category concerns economic and social rights that are dealt with in detail and embrace, inter alia, the access to free placement services and the right to protection against unjustified dismissal "in accordance with Union law and national laws and practices".

As regards application, Article II-51(2) states that the Charter is not intended to expand the field of application of EU law beyond already existing powers, establish new powers or tasks or modify powers and tasks contained in other parts of the Constitution.

\section{The Intergovernmental Conference of 2003-2004}

The draft Constitution provided a starting point for the IGC called to hammer out the final text. The IGC officially opened on 4 October 2003 in Rome and was expected, at least in some quarters, to approve in a matter of weeks the constitutional treaty redesigning the EU. However, by early December 2003 it became apparent that an agreement on the Constitution could not be reached easily and that much more time was needed for negotiation on the most contentious issues. The impossibility to reconcile 
『日本 $\mathrm{EU}$ 学会年報』第 24 号, 平成16年 9 月

the differences among some of the 25 participating countries was openly recognized by the European Council meeting on 12 December 2003 in Brussels.

In fact, the bulky text delivered by the Convention presented a remarkable challenge to the IGC, torn between the temptation to embark on a wide-ranging reappraisal of the draft and the prospect of confining itself to minor changes without touching to the substance of the choices already made. It is beyond doubt that any endeavour to revisit a number of subjects involves the risk of opening Pandora's box, with unforeseen consequences for the whole process of European integration.

The small and medium-sized countries are worried by attempts on the part of large member countries to dominate negotiations at the IGC and impose their own views. This is especially the case for some of the institutional arrangements formulated by the conventioneers. In particular, as regards the proposed European Council Chair, no longer subject to the six-month rotation rule, the "smalls" are concerned about the possibility that the president will emerge as a dominant figure ultimately answering to the big partners, especially France, Germany and the UK. The relationship of the European Council's president with the EU foreign minister and with the president of the Commission might become a source of conflict, eventually reducing the powers of the Commission itself.

Austria and Finland coordinate the group of "like-minded countries" that insist on the right for each member country to have its own European commissioner with voting powers. As a matter of fact, the arrangement proposed in the draft Constitution would prevent some member countries from appointing their own "representative" in Brussels. The prospect of having either a "second-class" commissioner or no commissioner at all would doubtless be distressing for countries like those of central and eastern Europe that since only a decade or so have regained their full sovereignty.

It should be emphasized, however, that the rigid principle of one 
The EU Expansion and the Draft Constitution: A Redesigned Europe for the 21st Century? (Schiavone)

commissioner per country in an enlarged Union raises some perplexities. Its adoption would inevitably strengthen the wrong belief that commissioners are the cabinet ministers of an EU government appointed to promote their respective national interests rather than the guarantors of the Union's interest and the driving force for integration. On the other hand, the introduction of a distinction between two categories of commissioners, belonging respectively to an "A League" and a "B League", could have an adverse impact on the authority and efficiency of the Commission.

On the practical side and whatever the formula that will eventually be adopted, the fact remains that there are not enough portfolios to be equitably allocated among all the members of the "college" of commissioners. Proposals have been put forward for setting up a number of minicabinets, each one run by a senior commissioner with a team of junior commissioners, to take decisions in the most sensitive areas and ensure coordination. The possibility of appointing a Vice-President of the Commission to act as Economics Minister is also being considered. In any case, a hierarchy of commissioners is likely to emerge, especially if plans to reorganize portfolios within the Commission are implemented.

As regards qualified majority, the "Nice formula" that openly favours medium-sized countries, more precisely Spain and Poland, in the Council of Ministers would be substituted in 2009 by a system giving more weight to large countries such as Germany. Spain and Poland, however, remain firmly opposed to any dilution of their voting powers secured at the December 2000 European Council in Nice. Whatever the final decision of the IGC on this controversial issue, the new formula appears in many respects both simpler and more democratic than the system adopted in Nice.

Efforts to rescue the draft Constitution have been undertaken by the Irish presidency during the first half of 2004. It seems highly unlikely, however, that the Constitution would be ready, in all of the EU's soon-tobe-21 official languages, before the elections of the European Parliament 
scheduled to take place by mid-June 2004 .

In order to enter into force, the final version produced by the IGC must be ratified by all 25 member countries, with some countries due to have referendums. It should be kept in mind that ratification, as the Convention's Chairman Giscard d'Estaing has appropriately warned, is "not a foregone conclusion". A crucial issue is in fact represented by the national referendums to be held on the Constitution that might turn into a broader vote of confidence in the $\mathrm{EU}$ as such. There is also the risk that, in some countries, the referendum could become a catalyst for political protest against the government, without any direct link to issues raised in the constitutional treaty. A number of current and acceding members are almost certain to hold a referendum:Denmark, Ireland, the Netherlands, Portugal, Spain and the Czech Republic. They might eventually be joined by Finland, France, Italy and Poland.

On the other hand, it may well be that the national electorate that casts a negative vote will be presented again with a slightly modified version of the text so as to eventually enable voters to make the "right" decision. The examples of Denmark in 1992 with the Maastricht Treaty and of Ireland in 2001 with the Nice Treaty easily come to mind.

It is important to emphasize that the draft Constitution does not introduce any change to the rules that currently govern the revision of treaties. Article IV -7 states that any future amendment to the Constitution will require unanimous agreement from the governments of all member countries and subsequent ratification by all of these countries, in keeping with their domestic requirements. In order to simplify the process, proposals have been put forward to attribute "constitutional" rank only to the first two parts of the Constitution that would thus remain subject to the present ratification rules. A more flexible and simpler formula would be contemplated for the other two parts, avoiding lengthy and often cumbersome constitutional procedures when non-essential provisions of the text have to be amended. 
The EU Expansion and the Draft Constitution: A Redesigned Europe for the 21st Century? (Schiavone)

\section{Enlarging versus deepening : a never-ending dilemma?}

The basic principles and goals of European integration shared by the Six founder members of the Communities in the 1950s are being turned into a pan-European reality. The common values of pluralist democracy, economic freedom, human rights and the rule of law have now been placed at the heart of the European identity.

Although the importance of an enlarging versus deepening problem may sometimes appear to be overstated, the fact must be recognized that not all the countries involved in the "grand design" of European integration are able, interested and prepared to move forward at the same pace. It was the Tindemans Report of 1975 that put forward the notion of different "speeds" in the process of European integration (Europe à deux vitesses). A number of models have subsequently been suggested, with more or less fortune, from "concentric circles" to Europe à la carte, from "variable geometry" to "multi-speed" Europe to "differentiated integration".

Whatever the formula, the basic idea remains of a distinction between "core" activities in which all members fully participate and other areas in which members decide whether and when to be involved. Depending on the model adopted, this may lead in practice either to varying combinations of countries implementing different policies at different speeds or to the establishment, on a permanent basis, of a leading group of countries more "equal" than others, followed by second-rank members, a division clearly unacceptable, at least in principle, by the latter.

The growing demand for flexibility in the integration process, to meet the needs of existing as well as would-be members, had already been recognized, to some extent, by the Amsterdam Treaty with the incorporation, in the Treaty on European Union (TEU), of a new heading (Title VII) devoted to "Provisions on closer cooperation". More precisely, Article 43 of the new Title stated that countries "which intend to establish closer cooperation between themselves may make use of the institutions, procedures and mechanisms" laid down by the TEU and by the Treaty 
establishing the European Community (TEC), on the basis of an authorization granted by the Council. A number of conditions were listed, including the requisite that such cooperation "concerns at least a majority" of members, with a "veto" power granted to non-participating countries. Specific additional criteria were set by Article 11 of the TEC.

The Treaty of Nice redrafted the provisions on closer cooperation, renamed, in Title II of the TEU, "enhanced cooperation". According to the terms of Article 43 TEU currently in force, the proposed cooperation is subject to strict requirements; it must involve at least eight member countries and, once established, should remain open to all members interested to join at a later stage. Article $43 a$, inserted at Nice, affirms that enhanced cooperation "may be undertaken only as a last resort", after the Council has established that the proposed objectives cannot be attained, within a reasonable period, by applying the relevant provisions of the treaties. Acts and decisions adopted within the framework of enhanced cooperation are expressly excluded from the acquis communautaire (Article $44 \mathrm{TEU})$. In the area of common foreign and security policy, enhanced cooperation must relate to implementation of a joint action or a common position but may not be extended to cover "matters having military or defence implications" (Article $27 b$ TEU).

The rules contained in Article 11 TEC were also revised at Nice. Enhanced cooperation in areas covered by TEC must be authorized by the Council, deciding by qualified majority on a proposal from the Commission and after consultation of the European Parliament. According to Article $11 a$, countries willing to join an established form of enhanced cooperation must notify their intention to the Council and to the Commission. The Commission gives an opinion to the Council and, within four months, decides on the notification and on the relevant arrangements.

The draft Constitution deals with "enhanced cooperation" and with "structured cooperation", the latter being applied in the area of security and defence policy to those countries that fulfil "higher military capability 
The EU Expansion and the Draft Constitution: A Redesigned Europe for the 21st Century? (Schiavone)

criteria" and wish to enter "into more binding commitments in this matter with a view to the most demanding tasks" (Articles I-40 and II -213). Through the formula of "structured cooperation", closer links would be established, among a number of member countries, in military and defence matters, with the possibility for other members to participate at a later stage.

A mutual defence clause has been inserted in Article I -40(7) stating that if one of the participating countries "is the victim of armed aggression on its territory" the other participating countries will provide "aid and assistance by all the means in their power", in accordance with Article 51 of the United Nations Charter. Article III-213 (5) maintains that the "appropriate provisions relating to enhanced cooperation shall apply to the structured cooperation governed by this Article".

As regards "enhanced cooperation", Article III -322 ensures that such cooperation does not adversely affect the internal market or economic, social and territorial cohesion and respects the competences, rights and obligations of members that do not participate. Special rules apply to the common foreign and security policy, an area opened up by conventioneers to enhanced cooperation provided the Council of Ministers so decides. Unlike other areas, authorization to proceed with enhanced cooperation in the framework of the common foreign and security policy is essentially granted by the Council of Ministers, with the Commission confining itself to giving its "opinion" and with the European Parliament being involved only "for information" (Article III-325).

For the time being, it seems rather arduous to predict the possible areas where enhanced cooperation might effectively work. No initiative in this direction has been taken so far under the rules introduced by the Amsterdam Treaty and subsequently amended by the Nice Treaty. In any case, the concept is gaining ground of an inner core of fairly homogeneous countries, pursuing common policies in a number of key political, economic and security areas, with an outer circle of countries more loosely connected 


\section{『日本 $\mathrm{EU}$ 学会年報』第 24 号，平成16年 9 月}

and with no "veto" right to prevent the former from moving ahead with new projects and initiatives. This could reconcile to some extent the drive towards deeper integration with the political necessity of enlargement.

Over the past few years, European leaders have expressed their views on the future shape of a reunited continent and on the finalites politiques of the EU. In May 2000, at a lecture delivered at Humboldt University in Berlin to discuss the long-term goals of the EU, German foreign minister Fischer launched the idea of a Europe powered by a "centre of gravity", consisting of a group of members moving faster towards integration, with the possibility for other countries to join at a later stage. Fischer also called for the adoption of a Constitution (a "dream" that might come true after just a few years), a directly elected president and the setting up of two chambers in the European Parliament, of which one would have been composed of members from national parliaments.

Shortly afterwards, in June 2000, French president Chirac, in a speech also delivered in Berlin, while ruling out "the creation of a European super-state" replacing present nation-states, suggested that a "pioneer group" of countries be allowed to cooperate more closely, in areas such as defence and economic policy, under the coordination of some kind of secretariat. According to Chirac, France and Germany should have provided the very foundation of the "pioneer group" along with other selected countries.

The events of 11 September 2001 contributed to focus the attention of the EU and its member countries on the growing threat represented by international terrorism and the proliferation of weapons of mass destruction. A solidarity clause has been inserted in the draft Constitution at Article I-42 providing for joint action of the EU and its members, including the mobilization of the relevant military resources, to assist a member "victim of terrorist attack or natural or man-made disaster".

The prompt response of the European partners of NATO after the 11 September terrorist strikes with the declaration that the attacks against the 
US were considered attacks against all of them, on the basis of the mutual defence clause contained in Article 5 of the North Atlantic Treaty, was a significant display of European unity and transatlantic solidarity that however did not survive the Iraq crisis. The opportunity for the EU to speak with one voice on an issue of such international relevance was regrettably lost. Moreover, the unsuccessful conclusion of the IGC meetings on 12 and 13 December 2003 cast long shadows on the prospects for an early endorsement of the draft Constitution.

The "pioneer group" proposal launched by President Chirac has been further developed in early 2004 drawing on the experience of the eurozone, the 12- nation bloc using the single currency, and of the Schengen agreement, currently involving $13 \mathrm{EU}$ countries. Other selected areas to which the pioneer group formula could be applied include the economic governance of the eurozone, justice and security, and foreign policy and defence. According to conventional wisdom, because of the different membership of the various groups, based on a case-by-case approach, no permanent division would be established within the EU between leaders and laggards.

It must be stressed, however, that within the "variable geometry" pattern there would be, more often than not, a permanent leadership group involving large countries promoting initiatives of common interest. In the past, examples abound of the Franco-German axis (the directoire) setting the pace in several areas. The emerging trilateral cooperation between the British, French and German leaders has already caused concern in other member countries, worried about the establishment of an exclusive alliance attempting to dominate the $\mathrm{EU}$ and, for that matter, the whole continent.

What the new Europe of 25 seems to need most is a serious dialogue between old and new members on basic economic, social and security issues to meet the challenge of a near-doubling of membership and the increasing chances of discord and deadlock. Although it should be acknowledged that not all members need to be "equal" in all circumstances, the danger is to be prevented of a proliferation of "coalitions of the willing" 
pursuing their own policies. Only then will the promise of "a common future", contained in the draft Constitution, be accomplished.

1) For the sake of simplicity, reference will be made throughout the paper to the EU, despite the fact that the EU as such came into existence only on 1 November 1993, following the entry into force of the Maastricht Treaty.

2) A de facto enlargement had already occurred with the incorporation into the EU of the German Democratic Republic (GDR) as a consequence of its reunification with the Federal Republic of Germany (FRG) on 3 October 1990.

3) A particular case is that of Norway, fully aligned with western Europe as a founder member of NATO, which applied for EU membership twice, in April 1962 and December 1992. The relevant negotiations were successfully completed, but the respective draft accession treaties were rejected by popular referendums in September 1972 and November 1994, in both cases by a narrow margin. Another special case is represented by Switzerland which has concluded a series of agreements with the EU but whose membership remains controversial among the Swiss people. The Swiss application, in June 1992, to join the EU has fallen into abeyance after the rejection by referendum of the Agreement establishing the European Economic Area. Despite its consistent record of continued enlargement, the EU has suffered the withdrawal of one member. Greenland, which belongs to Denmark and had therefore become part of the EC in 1973, decided in 1982, on the basis of a popular referendum, to leave the Community. The EC agreed with the Danish government to allow Greenland to leave the Community on 1 January 1985, granting it the status of an associated overseas territory.

4) Another Convention, meeting between December 1999 and September 2000, had prepared the draft of the Charter of Fundamental Rights proclaimed at Nice.

5) It may well be that in the future the Convention method could eventually replace the current IGC formula, upgrading the Convention itself to the rank of constituent assembly.

6) In the 15-member EU the official languages total 12 since Irish is also included; after the entry of ten new members on 1 May 2004 official languages will rise to 21 .

7) In Philadelphia, 55 men, delegates from 12 of the 13 newly-independent colonies, met in secrecy for an entire summer and, in the end, only 39 of them approved the Constitution. The European Convention, for its part, involved to a considerable extent the civil society and was characterized by a remarkable degree of openness.

8) Draft Treaty establishing a Constitution for Europe, adopted by consensus by the European Convention on 13 June and 10 July 2003, submitted to the President of the European Council in Rome, 18 July 2003, CONV 850/03. For an assessment of the key 
The EU Expansion and the Draft Constitution: A Redesigned Europe for the 21st Century? (Schiavone)

features of the draft Constitution see J.Kokott and A. Rüth, "The European Convention and its Draft Treaty establishing a Constitution for Europe: Appropriate Answers to the Laeken Questions ?", in Common Market Law Review, vol. 40 (2003), pp. 1315-1345. See also B. de Witte (ed), Ten Reflections on the Constitutional Treaty for Europe, European University Institute, Florence, 2003.

9) The Treaty establishing the European Atomic Energy Community (Euratom), amended by a Protocol attached to the draft Constitution, will remain in force.

10) This was the case for an earlier draft of the Preamble which referred, inter alia, to Greek and Roman civilizations and to the Enlightenment; this mention was subsequently dropped.

11) The adoption of the new system would also bring to an end recurring arguments about the size of the "blocking minority" or, to put it the other way, the number of assenting votes ("threshold") necessary for approval of an act under the current QMV formula.

12) The following Chapter dealing with "other institutions and bodies" describes the role and competence of the European Central Bank, endowed with a legal personality of its own and independent in the exercise of its powers and for its finances, the Court of Auditors, and the two advisory bodies (the Committee of the Regions and the Economic and Social Committee).

13) According to the formula agreed in Nice, a single Spanish or Polish vote would represent about 1.4 million inhabitants, a single UK vote about 2 million and a single German vote about 2.8 million. Populations of Poland and Spain combined are still smaller than the population of Germany.

14) The above-mentioned mutual defence guarantee is patterned after the well-known Article 5 of the North Atlantic Treaty. The different security policy traditions of a number of current and acceding members, however, seem to make widespread acceptance of the mutual defence clause near to impossible. 


\section{The EU Expansion and the Draft Constitution: A Redesigned Europe for the $21^{\text {st }}$ Century?}

\section{GIUSEPPE Schiavone}

The enlargement from 15 to 25 member countries in May 2004 is the biggest single expansion of the EU since its establishment half a century ago and poses a formidable challenge both for the institutional structure and the decisionmaking process of the EU itself. The Communities first and the EU afterwards have gradually moved from trade and common market goals to a convergence of principles and values that have been enshrined in the draft Constitutional Treaty prepared by the Convention on the future of Europe between February 2002 and July 2003. The Constitutional Treaty, consisting of a preamble and four main parts for a total of 465 articles, is intended to replace all the existing instruments, that is the Treaty on European Union and the Treaty establishing the European Community as well as all the acts that have amended or supplemented them. The well-known "pillar structure" introduced by the Maastricht Treaty will also be abolished even if special procedures will continue to apply in the fields of foreign policy, security and defence. The fundamental principles governing the EU are embodied in Part I of the Constitutional Treaty which represents the "core" of the document and in a certain sense the "real" Constitution of the enlarged EU. The areas of competence of the EU are clearly described although the powers of the EU itself are not extended to a significant extent. Among the most important institutional changes of the Constitutional Treaty are the creation of a full-time post of President of the European Council, bringing to an end the current system based on six-month rotating presidencies, the appointment of the Union Minister for Foreign Affairs, and the substantial 
extension of the co-decision procedure to be implemented jointly by the Council of Ministers and the European Parliament. The move from the traditional formula of "weighted voting" to "double majority", based on the number of countries as well as on their population, has been another outstanding innovation of the document produced by the Convention. The provisions of Part II of the Constitutional Treaty give the EU its own catalogue of rights through the incorporation of the full text of the Charter of Fundamental Rights proclaimed in Nice in December 2000. The Intergovernmental Conference (IGC) was unable to approve the text of the Constitutional Treaty before the end of 2003 as widely expected; however, the Irish presidency managed to have the text approved by June 2004. Ratification of the Constitutional Treaty by all the 25 member countries should on no account be taken for granted and considerable challenges remain in the foreseeable future. While a permanent division within the EU between leading countries and second-rank members must be avoided, it should be possible for a "pioneer group" of countries to work harder to pursue initiatives of common interest in a number of key political, economic and security areas with the possibility for other members to join at a later stage, without compromising the prospect of a "common future" contained in the Consti. 